\title{
Accounting
}

\section{Monetary policy, exchange rate, renewable energy and economic growth: An empirical analysis of Vietnam}

\section{Nguyen Thi Viet Nga ${ }^{a^{*}}$}

\section{${ }^{a}$ Department of Economics, Academy of Finance, Vietnam}

\section{H R O N I C L E \\ A B S T R A C T}

\section{Article history:}

Received: November 30, 2020

Received in revised format:

April 32021

Accepted: April 4, 2021

Available online:

April 6, 2021

Keywords:

Monetary policy

Growth

Rate

Central bank

Renewable energy

\begin{abstract}
The aim of this study is focused on how monetary, energy consumption and other factors affect economic growth of the country of Vietnam. Based on collected secondary data covering from the World Bank and Vietnam's General Statistics Office from 1985 to 2019, and some data collected from the State Bank of Vietnam, Vector Autoregressive Model was considered to apply in order to investigate this relationship. Results show that there exists an association among monetary policy, renewable energy and the country's economic growth. Especially, the country's exchange rate shows no influence on its economic growth while interest rate has negative effects and particularly money supply and renewable energy have a positive influence on the same direction and has a strong impact on economic growth.
\end{abstract}

\section{Introduction}

C 2021 by the authors; licensee Growing Science, Canada

Monetary policy is known as the main factor of economy and its policy refers to the actions done by the central bank of a country for controlling both narrow and broad money supply in order to undertake the goals of banking system sustainability, interest rate stability, and for purposes of economic growth. Monetary policy is the most significant factor in macroeconomic governance. By influencing macro variables, monetary policy, exchange rate can affect how the government maintains stability and stimulates economic growth (Othman et al., 2020; Nguyen and Giang, 2020; Nguyen et al., 2020; Shobande \& Shodipe, 2019; Sulaiman \& Migiro, 2014). A large number of previous studies have confirmed that monetary policy and exchange rate in the central bank have a both direct and indirect effect on economic growth in increased and emerging economies (Nguyen et al., 2020; D.T. Nguyen, 2020; Nwoko et al., 2016). It is important to note that the influence of monetary policy and other macroeconomic factors on economic growth relies on the creation and operation of the central bank through instruments of monetary policy (Falade \& Folorunso, 2015; Nguyen, 2020; Nguyen, 2020; Son et al., 2020), and specific situation in each country. In the setting of global integration, a monetary policy has a great contribution to control both narrow and broad money supply to support and circulate capital flow of countries, and thereby causing a positive influence on economic growth and enhancement of lives quality. Therefore, being aware of the effects of monetary policy, exchange rate on economic growth is practically significant. Energy is the most important factor in economic progress (Nawaz et al., 2020). Over the recent decades, for getting up in the race of global economy the consumption of energy has increased in the Vietnam economy. Energy has played a significant role in the economy of Vietnam because without the involvement of the energy industry it could not be

* Corresponding author

E-mail address: nguyenthivietnga@hvtc.edu.vn (N.T.V. Nga)

(C) 2021 by the authors; licensee Growing Science, Canada doi: $10.5267 /$ j.ac.2021.4.007 
operated. That is the reason energy has greater influence on the economy of Vietnam. In the progress Vietnam's economy towards industrialization energy plays a vital role. Energy considered as input in production, transportation and distribution of all goods and services. That's why the discussion in relation to the association between energy and the country's economic growth (EG) was not easy to be stopped. It has been observed that per capita energy use in Vietnam increased by $9.3 \%$ annually from 1990 to 2007. The energy consumption from 55.6 Mtoe in 2007 to 146Mtoe in 2025 (Do and Sharma). It creates the attraction among economists and policymakers to analyze whether economic growth is caused due to consumption of energy. The rapid growing consumption of energy keeps bad effects on the environment. So, the need for the implications on environmental policies to protect the living creature from the bad effect of global warming and harmful diseases. Therefore to overcome and make the energy consumption friendly, apply renewable energy resources rather than traditional resources (Haq, Nawaz, Akram, \& Natarajan, 2020).

This study also contributes to investigate the impact of renewable energy along with monetary policy and exchange rate on economic development in Vietnam. There are five types of renewable energy like solar energy, bio energy, hydro energy, wind energy, and geothermal energy. Currently the traditional source of energy like fossil fuel and coal are used. These resources are limited and exhausted after usage. By consuming these traditional resources of energy may cause air pollution, land pollution and global warming. Chang et al. (2016) stated that the problems many other issues may occur like diseases in living creatures, badly effect on agriculture sector and heat problem on earth due to thickness of ozone layer respectively.

Vietnam is an economy which mostly depends on energy and any policy regarding energy usage and environment is the betterment and development of the economy. By taking into consideration the importance of connection of energy and economic growth, the only solution is to adopt renewable energy resources. As the infinite and non-exhausted energy are the characteristics of renewable energy. These sufficient resources of energy help to speed up the growth of Vietnam's economy. Dogan and Seker (2016) stated that renewable energy is cause to "raise developing countries to the track of the race of developed countries". In other sense, a country's economy can be developed by stabilizing the supply capacity and enhancing the energy demand through renewable energy resources.

Moreover, Le et al. (2016) suggested the solution of problematic issues that renewable energy is affordable, reliable and infinite with the characteristics of energy security, energy diversification and reduction of greenhouse gas emissions. These beneficiary factors make socioeconomic growth and also protect the environment. Most of the countries from all over the world are converting from fossil fuel to renewable energy but China and the United States take initiative in this field. Although China is considered a pioneer country to start up renewable energy, they were successful to produce 19\% of its total electricity (Luong, 2015). Same as the US could generate renewable energy $15 \%$ of total electricity consumption. The top ten countries that are taking benefits from renewable energy. The benefits of renewable energy are multi dimensions. The beneficiary factors support several sectors in the development of the country's economy. As in this sector no environmental damage exists. In this regard, job creation is the most important benefit for the emerging economy like Vietnam. It is expected that the overall capacity of work in the renewable energy sector is 5.7 million individuals. In this context China indulges 1.75 million people in the renewable energy division. European Union countries provided a workforce in this sector and Brazil also took initiative to involve 0.8 million people in the renewable energy sector (McPherson \& Tahseen, 2018).

Hence the renewable energy sector has a capacity to stabilize economic growth and financial wellbeing as well as provide societal benefits. It should be converted from traditional sources of energy to renewable energy specially emerging economies (Chien et al., 2021; Sadiq et al., 2020; Chang, Huang, \& Lee, 2009). It may cause job creation, enhance household income and improve the living standard of people. Vietnam has God gifted natural resources. It has characteristics as a tropical country, the development of the agriculture sector is caused by the favorable environmental condition(Bölük \& Mert, 2014). The natural condition may allow us to generate bio energy (Van Nguyen et al., 2016). Vietnam has a potential capacity of 318,000 MW of bio energy is higher than its production capacity i.e. $270 \mathrm{MW}$ in reality, as of 2018 . Geothermal energy is considered as the second most important source of renewable energy of Vietnam. The maximum concentration to fulfill the requirement of energy is through hydro energy resources in Vietnam (Paramati, Sinha, \& Dogan, 2017). In this regard, the Government should design energy policies by keeping the outfits of renewable energy in mind. This study is beneficial for economists, policy makers, top management in the government-owned office and the corporate as well.

This paper is organized as follows; Section 2 will discuss literature review while Section 3 has data, research methodology. More importantly, Section 4 will analyze empirical results. At last, Section 5 mentions conclusions and the policy implications.

\section{Literature review}

The word economic growth literally means welfare and societal benefits. Growth is meant per capita of total market value of all finished goods in one year, the average production of a country and business statistics calculated by division of GDP with total population of the country. Law and Singh (2014) stated that to obtain a stable economy at optimal level is the most priority of any country. Many factors are involved to determine the economic growth of any country such as human capital, exports, financial development, and learning by doing business. Human capital is long regarded as a driver of the country's economic 
growth. The term human capital is referred to as the knowledge, skill, experience of humans which value and cost to an organization or economy (Isik, Dogru, \& Turk, 2018). Human capital can be estimated by taking the consideration of enrolled students in universities and colleges in any country who will become the part of economic growth in future. Learning by doing is another determinant of economic development. It shows a positive influence on economic growth. In ASEAN-5 economies from 1970-1996 it is found that learning by doing through technology has potential to economic growth. The growth theory presented by Hermes and Lensink (2013) has explained that an increase in export may cause the economic growth of a country. Export has a potential to create and promote the growth-accelerating forces. All technological progress and industrial production can be absorbed through export and this implies a positive impact on GDP (García-Muñiz \& Vicente, 2014). The positive association occurs between the status of financial development and the rate of economic growth. Domestic investment may cause a boost to the economy of a country. Economic growth is on account of the development of the financial system of a host country (Sadiq et al., 2020; Soytas \& Sari, 2009). The process of technological diffusion has been positively contributed by the well-developed financial system.

Monetary policy is a part and a tool of macro policy, and significantly plays a stabilizing role in affecting economic growth. The primary goals of monetary policy can affect job creation, economic development, interest rate stability, price stable level, finance market stability, and stock market stability (Azman-Saini \& Law, 2010). Therefore, the central bank in each economy may consider some important tools like required reserve ratio, open market operations, and lending discounts in order to revise and manage their economies (T. T. Le \& Luong, 2020). In addition, by using transmission channels, such instruments have particular effects on investment, interest rates, and real GDP. The monetary policy played a significant role in the economic growth of the country. If the government has developed the favorable monetary policy then it has a positive impact on the economic growth of the country and if the government has developed the unfavorable monetary policy then it has an adverse impact on the economic growth of the country.

Theoretically, the influence of government monetary policy on economic growth is dependent on many factors, including the flexibility of interest rates to money requirement, employment rate, and political system. According to Sean (2019) who shows that monetary policy with its proxies as money supply, inflation and exchange rate have a positive relationship to economic growth in the state of Cambodia. Similarly, Bhattacharya et al. (2009)with a question whether central banks should implement Friedman rule in their operation policies, a mild scale of social enhancing profitability is sufficient for positive inflation to overtop zero inflation, and Friedman rule will be sub-optimal. In respect to the relationship between monetary policy of Sulaiman et al. (2014) found that a link between interest rate, exchange rate and the country's economic growth can be found whereas the cash reserve coefficient and money supply have negligible effects, therefore, this linkage is one-way causality. Further discussed on this, Sulaiman and Migiro (2014) also shows, there is no causality from GDP to monetary policy variables.

With the same study situation, Kilinc and Tunc (2019) conduct a study in Turkey by using a quarterly data covering in the duration from 2006/Q1 to 2017/Q4 and implementing the Markov Switching Model. Results indicate that fluctuations in monetary policy shows stronger influence on economic growth, industrial production in the contractionary periods, but much weaker in the expansionary periods. In addition, Nwoko et al. (2016) tested the influence of monetary policy in Nigeria and how it stimulates economic growth covering from 1990 to 2011. Using multiple regression models and Ordinary Least Square methods for the analysis of the linkages between money supply, interest rate, price level, and the labor force on GDP. Importantly, monetary policy was efficient in making adjustments among the unemployment rate, output, price, and the economy growth. Additionally, mean price level and especially labor force can create a powerful influence on GDP while money supply has an influence on GDP, whilst interest rate has a negative but ignorable influence on GDP.

As shown by Twinoburyo and Odhiambo (2018) on a study about how monetary policy affects economic growth, and he found that it did not influence economic growth in the long term period but it has an influence on the interest rate transmission channel in the short term. In addition to interest and exchange rate, inflation, money supply, Shobande and Shodipe (2019) in a study to confirm that these factors can impact on Nigeria's economic growth. In fact, interest rate, trade balance, and home credit show a positive and significant impact on economic growth in the long run. In addition, monetary policies have a greater impact on the economy both negative and positive depending on the nature of the monetary policy. If monetary policy adjusts with the economic conditions of the country then it puts a positive and significant impact on the economic growth of the country but if monetary policy does not adjust with the economic conditions of the country then it puts a negative impact on the economic growth of the country.

Many studies have been revealed in the past with the discussion of multivariate like carbon emission, financial development, and the country's economic growth. Most of the finding of this research is the causal effect with renewable energy and economic growth. To clear the concept of renewable energy it is defined as the sources which are unlimited like tide, air, solar, rain, wave and geothermal energy. These resources are considered as infinite having two categories (1) energy cannot be exhausted like solar energy, water energy and wind energy (2) renewable energy has a characteristic of self- renewed within short time and this is continuous process biomass energy is the good example in this regard (Wei et al., 2020). Geothermal energy refers to the energy extracted from heat in the earth's interior (Kahia et al., 2017). This energy is formed from the beginning of the planet, radioactive decay of minerals and solar energy. Plants and animals cause the production of bioenergy which is considered as 
organic sources. Kinetic of the wind may cause the wind energy (Salim et al., 2014). From the light and heat of the sun solar energy is generated. Water power derived hydro energy. Most of the dams generated hydro energy that spin turbines and generators in spite of electricity. These unlimited sources of renewable energy are free from environmental damage and economically efficient for a long run and fulfill the requirement of energy (Bhattacharya et al., 2016).

In addition, Nong et al. (2020) argued that economic growth has been achieved by renewable energy. It is very crucial for the development and promotion of life lifestyle of the nation to ensure energy security. To provide unlimited, reliable and infinite energy at an affordable price to the nation is the basic goal of energy security. It is comparatively better than fossil fuel and coal energy (Bloch, Rafiq, \& Salim, 2015). Environmentally friendly is the only quality of renewable energy resources (Zhao et al., 2011). Competitiveness to a nation has been perceived with these benefits. Moreover, Nong et al. (2019) stated in promoting the association between renewable energy and GDP. As the consumption of energy increases, the GDP of the economy will increase as result. By taking the data from 28 countries specify the calculation, $0.120 \%$ GDP growth is due to the $1 \%$ increase in renewable energy, by $0.162 \%$ of GDP per capita, by $0.444 \%$ rural households' per capita annual income, and by $0.368 \%$ urban households' per capita annual income. In addition, renewable energy has also significant impact on the economic growth, If the financial conditions are better in the country then the industry and other sectors are working with their full capacity that consume the energy but if financial conditions are not good then the industry and other sectors are not working properly and consume very small amount of energy. Thus, if the renewable energy consumption increases in the country it means that the country improves its economy. Therefore, renewable energy can contribute a greater part to boost up the economy of Vietnam in the future. As renewable energy is used instead of traditional energy from coals and fossil fuels. The relationship between renewable energy and economic growth is positive in the context of Vietnam (Sasana \& Ghozali, 2017). Thus, based on the above literature, the economic growth is the function of monetary policy, exchange rate and the use of renewable energy and this study also analyzes the influence of monetary policy, exchange rate and the consumption of renewable energy on economic growth.

\section{Data and research methodology}

The study uses a time-series sample data collected from the World Bank and Vietnam's General Statistics Office covering from 1985 to 2019, and some data collected from the State Bank of Vietnam. In this research, we will select variables and the development of the research hypotheses are mostly on the basis of literature review, mostly from the work of Sulaiman and Migiro (2014); Shobande and Shodipe (2019), Kilinc and Tunc (2019). Specifically, the model is written in the following equation:

$$
G D P=f(M S, E X C, M R, I N F, R E N G)
$$

The above model can be rewritten as a regression model:

$$
G D P_{t}=\alpha_{0}+\beta_{1} M S_{t}+\beta_{2} E X C_{t}+\beta_{3} M R_{t}+\beta_{4} I N F_{t}+\beta_{5} R E N G_{t}+e_{t}
$$

where,

GDP is the gross domestic product, representing the economic growth,

$\mathrm{MS}$ is the money supply,

$\mathrm{EXC}$ is the USD/VND rate,

INF is the inflation rate,

$\mathrm{MR}$ is the market rate,

RENG is the renewable energy consumption

$\varepsilon$ is the statistical error,

$\alpha_{0}$ isthe intercept, and $\beta_{1}, \beta_{2}, \beta_{3}, \beta_{4}, \beta_{5}$ is the coefficient of independent variables.

On the basis of the recent studies, the interest rate variables selected for testing include short term (MR_S) and long term (MR_L).

According to Sulaiman and Migiro (2014); Kilinc and Tunc (2019), and Mukherjee, Chakraborty, and De (2020) further discussed on the link between monetary policy, renewable energy and economic growth in the case of Vietnam, based on research objectives, the study figures out the following research hypotheses:

$\mathrm{H}_{0}$ : Monetary policy does not have a significant influence on economic growth.

$\mathrm{H}_{1}$ : Monetary policy has a significant influence on economic growth. 
$\mathrm{H}_{0}$ : Renewable energy does not have a significant effect on economic growth.

H1: Renewable energy has a significant effect on economic growth.

\section{Empirical results}

In this section, by applying time-series data, and the model of VAR method. We will analyze the relationship between monetary policy, renewable energy and economic growth in the case of Vietnam. First, we discuss descriptive statistics for dependent and independent variables. The results show that 35 observations are used by the study whole; it also shows the mean, minimum, maximum values and standard deviation of the variables. The results show that average value of GDP is 6.82 while standard deviation is 2.121 and minimum and maximum values are 5.32 and 9.86 respectively. In addition, the results also show that average value of inflation is 6.65 while standard deviation is 5.678 and minimum and maximum values are 0.63 and 21.23 respectively. Moreover, the average value of MS is 4.75 while standard deviation is 2.23 and minimum and maximum values are 1.98 and 8.78 respectively. Furthermore, average value of EXC is 16770.19 while standard deviation is 1524.12 and minimum and maximum values are 3065.08 and 23602.05 respectively. Finally, the average value of RENG is 0.54 while standard deviation is 0.32 and minimum and maximum values are 0.25 and 0.62 respectively. These results obtained in Table 1 as follows:

\section{Table 1}

Descriptive statistics

\begin{tabular}{|c|c|c|c|c|c|}
\hline Variable & Number of observations & Mean & Standard Deviation & Min & Max \\
\hline GDP & 35 & 6.82 & 2.121 & 5.32 & 9.86 \\
\hline MR_S & 35 & 6.32 & 2.112 & 5.32 & 8.67 \\
\hline MR_L & 35 & 9.54 & 2.563 & 6.09 & 24.45 \\
\hline INF & 35 & 6.65 & 5.678 & 0.63 & 21.23 \\
\hline MS & 35 & 4.75 & 2.23 & 1.98 & 8.78 \\
\hline $\mathrm{EXC}$ & 35 & 16770.19 & 1524.12 & 3065.08 & 23602.05 \\
\hline RENG & 35 & 0.54 & 0.32 & 0.25 & 0.62 \\
\hline
\end{tabular}

Source: Result from Stata

Table 1 discusses the descriptive statistics, for example, maximum values of the variables of the variables. The figures show that interest rates are quite high because the economy is exposed to a financial crisis in the period of 2011-2013. Table 1 also shows that long-term interest rates fluctuate during the economic crisis, which focuses on the period from 2009 to 2013 , from 2014 to 2018, long-term interest rates at the average is about approximately $10 \%$. The rapid increase in money supply of the economy over the years showed an important effect of the interest rate tool in the managing of monetary policy from the State bank of Vietnam. The test results in Table 2 show all data series along with economic growth, inflation, short-run interest rates, long-run interest rates, exchange rate and money supply are fixed at the real data series of $1 \%$ significance level. Therefore, the theory concludes that the VAR model is more suitable for this research. In the VAR model, each variable is seen as a linear combination of past values of itself.

Table 2

Results of the stationary test

\begin{tabular}{lc}
\hline Variable & At level \\
\hline GDP & 0.023 \\
MR_S & 0.062 \\
MR_L & 0.034 \\
INF & 0.071 \\
MS & 0.043 \\
EXC & 0.0032 \\
RENG & 0.025 \\
\hline
\end{tabular}

Source: Result from Stata

In this case, we use the VAR method to determine the optimal lag length, results are presented in Table 3 as follows:

Table 3

The test of maximum lag for variables in the model

\begin{tabular}{|c|c|c|c|c|c|c|c|c|}
\hline \multicolumn{9}{|c|}{ Selection-order criteria } \\
\hline \multicolumn{9}{|c|}{ Sample: 1985-2019 } \\
\hline Lag & LL & LR & $\mathrm{df}$ & $\mathrm{P}$ & FPE & $\mathrm{AIC}$ & HQIC & SBIC \\
\hline 0 & 26.321 & & & & $7.3^{*}$ & -9.725 & -10.552 & -10.022 \\
\hline 1 & 681.532 & 1237.0 & 16 & 0.00 & . & -262.730 & -286.923 & -274.206 \\
\hline 2 & 755.123 & $92.13 *$ & 16 & 0.00 & . & $-281.743^{*}$ & $-295.935^{*}$ & $-293.505^{*}$ \\
\hline 3 & 738.038 & -40.655 & 16 & . & . & -273.203 & -289.404 & -284.785 \\
\hline 4 & 742.130 & 21.212 & 16 & 0.051 & . & -278.036 & -295.279 & -289.624 \\
\hline
\end{tabular}

Source: Result from Stata

According to the VAR model, the results obtained in Table 4 with the lag of 1 show that the variables DGDP, DRENG and 
DMS have a positive influence on DGDP with the significance level of 5\%, the variable DMR_S, DMR_L, DINF had a negative effect on DGDP with the significance level of $1 \%$.

Table 4

Results of VAR model analysis

\begin{tabular}{|c|c|c|c|c|c|}
\hline Variables & Parms & RMSE & R-sq & Chi2 & P > chi2 \\
\hline DGDP & 33 & 0.0293 & 0.8233 & 41.4554 & 0.0001 \\
\hline DMR_S & 33 & 0.1022 & 0.9045 & 74.6612 & 0.0002 \\
\hline DMR_L & 33 & 0.06644 & 0.9235 & 106.2056 & 0.0002 \\
\hline DINF & 33 & 1.1487 & 0.6176 & 12.9021 & 0.0242 \\
\hline DMS & 33 & 0.0372 & 0.7256 & 20.7654 & 0.0022 \\
\hline DRENG & 33 & 0.0542 & 0.5324 & 21.3621 & 0.0021 \\
\hline
\end{tabular}

Source: Result from Stata

In order to check stability, Fig. 1 shows that the solutions are in the unit circle, so the VAR model with delay 1 is stable and consistent.

\section{Inverse Roots of AR Characteristic Polynomial}

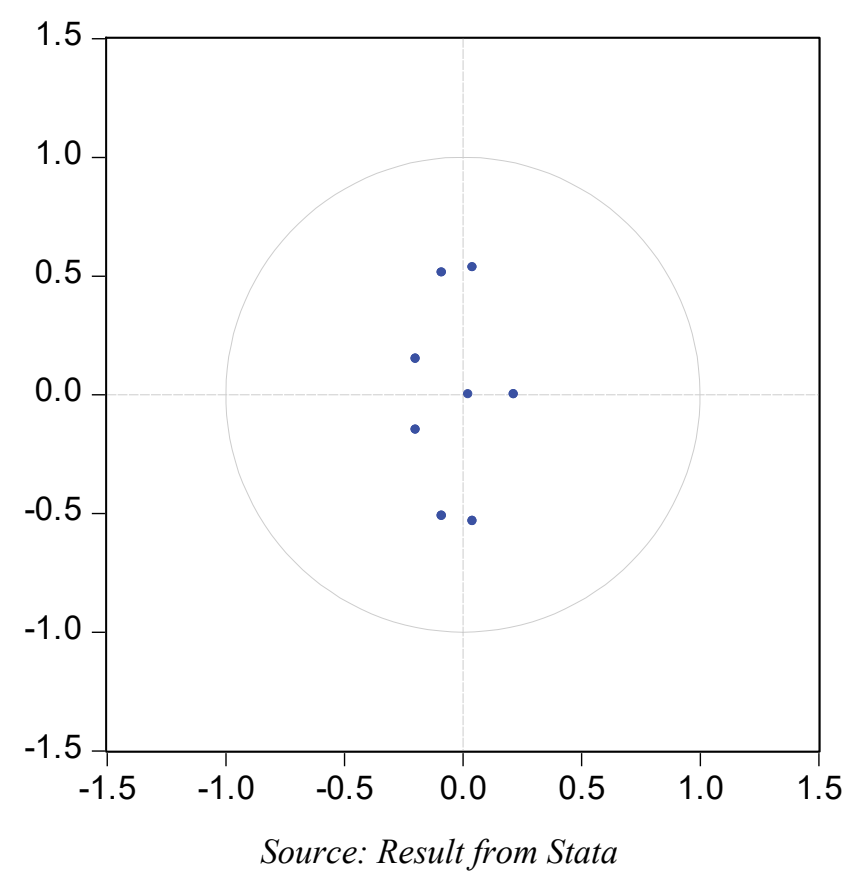

Fig. 1. Model stability test

Table 5

Regression model results

\begin{tabular}{lcccccccccccc}
\hline \multirow{2}{*}{ Variable } & \multicolumn{2}{c}{ DGDP } & \multicolumn{2}{c}{ DMR_S } & \multicolumn{2}{c}{ DMR_L } & \multicolumn{2}{c}{ DINF } & \multicolumn{2}{c}{ DMS } & DRENG \\
\cline { 2 - 12 } & Beta. & P.V. & Beta. & P.V. & Beta. & P.V. & Beta. & P.V. & Beta. & P.V. & Beta. & P.V. \\
\hline Cons & 0.03201 & 0.132 & 0.05452 & 0.494 & .2103 & 0.000 & 1.3288 & 0.152 & 0.1770 & 0.000 & 0.32 & 0.00 \\
DGDP & 0.31434 & 0.120 & -3.2659 & 0.000 & -3.5514 & 0.001 & -5.4881 & 0.441 & 0.7665 & 0.002 & 0.14 & 0.00 \\
DINTS & 0.1047 & 0.350 & 0.44334 & 0.305 & 1.0293 & 0.020 & -5.1564 & 0.239 & -0.0572 & 0.721 & 0.39 & 0.01 \\
DINTL & 0.03125 & 0.760 & 0.2348 & 0.533 & -.47057 & 0.055 & 6.7696 & 0.022 & 0.003 & 0.932 & 1.32 & 0.02 \\
DINF & 0.00411 & 0.978 & 0.02053 & 0.744 & -0.0375 & 0.045 & 0.0679 & 0.839 & -0.0142 & 0.341 & 0.36 & 0.00 \\
DM2 & 0.18574 & 0.289 & 1.0260 & 0.043 & 0.5588 & 0.132 & -6.1779 & 0.357 & -0.2950 & 0.161 & 0.13 & 0.21 \\
DRENG & 0.05 & 0.02 & 0.521 & 0.031 & 0.091 & 0.012 & 0.023 & 0.02 & - & 0.32 & 0.09 & 0.00 \\
\hline
\end{tabular}

Source: Result from Stata

Table 5 indicates hypothesis $\mathrm{H} 1$ on the association among monetary policy and EG. Relating the level of monetary policy and its impact on EG, hypothesis $\mathrm{H} 1$ is also accepted. This means that monetary policy has positive association with the economic growth of Vietnam. It also indicates hypothesis $\mathrm{H} 2$ on the relationship between renewable energy and economic growth. Regarding the level of renewable energy and its impact on economic growth, hypothesis $\mathrm{H} 2$ is also accepted. The results exposed that both monetary policy and renewable energy have positive along with significant association with EG of Vietnam. Thus, it is approved that renewable energy has positive association with the economic growth of the country in Vietnam. Therefore, it concludes that monetary policy tools including interest rates and money supply have a powerful influence, with a significance 
level of $1 \%$, while inflation also has an impact but with a lower significance. In addition, it also concludes that renewable energy has a powerful influence, with a significance level of $1 \%$.

\section{Discussions}

As for the money supply and its impact, if the money supply increases, economic growth can be enhanced. In addition, rising inflation rate reduces economic growth because of the effect from investors' real interest rates. These results match with the theory and particularly similar to the empirical results of the Bhattacharya et al. (2009), Kilinc who also exposed that the inflation rate has positively associated with the economic growth. If the inflation situation exists in the country then the chance of economic growth also increases and vice versa. These outcomes are also matched with the findings of the Tunc (2019) who also investigated the high inflation rate and high economic growth of the country. In addition, the outcomes are also in line with the findings of Sean (2019) who also investigated that economic growth of the country increases when the inflation situation exists in the country. Accordingly, empirical studies have significantly clarified the relationship between interest rates for short-run loans or long-run loans and policy rates. The effective use of energy resources could increase economic growth and this outcome is matched with the output of Pirlogea and Cicea (2012) who also exposed that effective use of energy resources has the ability to enhance the economic growth in the country. Moreover, the findings of the current study about the positive association among the interest rate and economic growth are also similar to the outcomes of the J. Bhattacharya et al. (2009) who also investigated that the high interest rate is the indication of high economic growth in the country. The financial condition in the country fixed the interest rate and if the financial conditions are better in the country then the interest rate is high and vice versa. Thus, if high interest rates exist it means better financial condition and high economic growth. In addition, the findings related to the positive association among the nexus of renewable energy consumption and economic growth are also in line with the output of Destek and Aslan (2017) who also investigated that if the renewable energy is effectively used by the country then the growth in the economy will boost up accordingly. If the financial conditions are better in the country then the industry and other sectors are working with their full capacity that consumes the energy but if financial conditions are not good then the industry and other sectors are not working properly and consume very small amounts of energy. Thus, if the renewable energy consumption increases in the country it means that the country improves its economy. These outcomes are also similar to the output of the Nong et al. (2019) who also exposed that the effective use of renewable energy like use in the increase in the production of the country could increase the economic growth of the country.

\section{Conclusions and policy implications}

By using time-series data collected from 1985 to 2019 and all series are stationary at the level so it is suitable for this research applying the VAR model to test the influence of monetary policy, renewable energy on economic growth in the case of Vietnam. Factors in this research include lending rates, inflation, money supply, renewable energy consumption and exchange rates. Based on findings, it shows that there is a relationship between monetary policy, renewable energy and economic growth. In particular, the exchange rate has no influence on economic growth while interest rates have negative effects and particularly money supply has a positive impact on the same direction and has a strong impact on economic growth. Renewable energy shows a positive influence on the economic growth of Vietnam. In this paper, we cannot find the relationship between factors in the long run because of the existence of cointegration. In this regard, the Government should design energy policies by keeping the outfits of renewable energy in mind. This study is beneficial for policy makers, economists, top management in the government-owned office and the corporate as well.

The results obtained in this research also support some recommendations. Firstly, monetary policy is operated with the aim to create a favorable environment to encourage domestic and foreign investment by maintaining a suitable regime of interest rates and exchange rates in the economy. It is especially necessary to apply technical measures to attain the support of commercial banks such as achieving their target of lowering interest rates, helping to stimulate economic growth. In addition, it is also necessary the effective use of energy practices should be followed by the country that could be favorable for the economic growth of the country.

Secondly, the research recommends that the central bank should pursue a tight monetary policy as not like previous periods of State bank of Vietnam or central banks in other emerging economies, the adjustment to reduce the operating interest rate will assist commercial banks to approach with the State Bank's capital at lower costs, assisting the reduction in the cost of capital for the economy in general and businesses in particular.

\section{References}

Azman-Saini, W. N. W., \& Law, S. H. (2010). FDI and economic growth: New evidence on the role of financial markets. Economics Letters, 107(2), 211-213. doi: https://doi.org/10.1016/j.econlet.2010.01.027

Bhattacharya, J., Haslag, J., \& Martin, A. (2009). Optimal monetary policy and economic growth. European Economic Review, 53(2), 210-221. doi: https://doi.org/10.1016/j.euroecorev.2008.03.003

Bhattacharya, M., Paramati, S. R., Ozturk, I., \& Bhattacharya, S. (2016). The effect of renewable energy consumption on economic growth: Evidence from top 38 countries. Applied Energy, 162, 733-741. doi: 
https://doi.org/10.1016/j.apenergy.2015.10.104

Bloch, H., Rafiq, S., \& Salim, R. (2015). Economic growth with coal, oil and renewable energy consumption in China: Prospects for fuel substitution. Economic Modelling, 44, 104-115. doi: https://doi.org/10.1016/j.econmod.2014.09.017

Bölük, G., \& Mert, M. (2014). Fossil \& renewable energy consumption, GHGs (greenhouse gases) and economic growth: Evidence from a panel of EU (European Union) countries. Energy, 74, 439-446. doi: https://doi.org/10.1016/j.energy.2014.07.008

Chang, T.-H., Huang, C.-M., \& Lee, M.-C. (2009). Threshold effect of the economic growth rate on the renewable energy development from a change in energy price: Evidence from OECD countries. Energy policy, 37(12), 5796-5802. doi: https://doi.org/10.1016/j.enpol.2009.08.049

Chang, Y., Fang, Z., \& Li, Y. (2016). Renewable energy policies in promoting financing and investment among the East Asia Summit countries: Quantitative assessment and policy implications. Energy policy, 95, 427-436. doi: https://doi.org/10.1016/j.enpol.2016.02.017

Chien, F., Sadiq, M., Kamran, H.W. et al. Co-movement of energy prices and stock market return: environmental wavelet nexus of COVID-19 pandemic from the USA, Europe, and China. Environ Sci Pollut Res (2021). https://doi.org/10.1007/s11356021-12938-2

Destek, M. A., \& Aslan, A. (2017). Renewable and non-renewable energy consumption and economic growth in emerging economies: Evidence from bootstrap panel causality. Renewable Energy, 111, 757-763. doi: https://doi.org/10.1016/j.renene.2017.05.008

Dogan, E., \& Seker, F. (2016). The influence of real output, renewable and non-renewable energy, trade and financial development on carbon emissions in the top renewable energy countries. Renewable and Sustainable Energy Reviews, 60, 1074-1085. doi: https://doi.org/10.1016/j.rser.2016.02.006

Falade, O. E., \& Folorunso, B. A. (2015). Fiscal and monetary policy instruments and economic growth sustainability in Nigeria. American Journal of Economics, 5(6), 587-594. doi: 10.5923/j.economics.20150506.04

García-Muñiz, A. S., \& Vicente, M. R. (2014). ICT technologies in Europe: A study of technological diffusion and economic growth under network theory. Telecommunications Policy, 38(4), 360-370. doi: https://doi.org/10.1016/j.telpol.2013.12.003

Haq, M. A. U., Nawaz, M. A., Akram, F., \& Natarajan, V. K. (2020). Theoretical Implications of Renewable Energy using Improved Cooking Stoves for Rural Households. International Journal of Energy Economics and Policy, 10(5), 546-554.

Hermes, N., \& Lensink, R. (2013). Financial development and economic growth: theory and experiences from developing countries: Routledge.

Isik, C., Dogru, T., \& Turk, E. S. (2018). A nexus of linear and non-linear relationships between tourism demand, renewable energy consumption, and economic growth: Theory and evidence. International Journal of Tourism Research, 20(1), 38-49. doi: https://doi.org/10.1002/jtr.2151

Kahia, M., Aïssa, M. S. B., \& Lanouar, C. (2017). Renewable and non-renewable energy use-economic growth nexus: The case of MENA Net Oil Importing Countries. Renewable and Sustainable Energy Reviews, 71, 127-140. doi: https://doi.org/10.1016/j.rser.2017.01.010

Kilinc, M., \& Tunc, C. (2019). The asymmetric effects of monetary policy on economic activity in Turkey. Structural Change and Economic Dynamics, 51, 505-528. doi: https://doi.org/10.1016/j.strueco.2019.03.006

Law, S. H., \& Singh, N. (2014). Does too much finance harm economic growth? Journal of Banking \& Finance, 41, 36-44. doi: https://doi.org/10.1016/j.jbankfin.2013.12.020

Le, T. H., Le, Q. V., Nguyen, T. P. T., Schnitzer, H., \& Braunegg, G. (2016). An integrated ecosystem incorporating renewable energy leading to pollution reduction for sustainable development of craft villages in rural area: a case study at sedge mats village in Mekong Delta, Vietnam. Energy, Sustainability and Society, 6(1), 21-25. doi: https://doi.org/10.1186/s13705-0160088-6

Le, T. T., \& Luong, A. T. (2020). A Test of Return Predictability in the Vietnamese Stock Market. International Journal of Financial Research, 11(2), 390-404. doi: doi:10.5430/ijfr.v11n2p390

Luong, N. D. (2015). A critical review on potential and current status of wind energy in Vietnam. Renewable and Sustainable Energy Reviews, 43, 440-448. doi: https://doi.org/10.1016/j.rser.2014.11.060

McPherson, M., \& Tahseen, S. (2018). Deploying storage assets to facilitate variable renewable energy integration: The impacts of grid flexibility, renewable penetration, and market structure. Energy, 145, 856-870. doi: https://doi.org/10.1016/j.energy.2018.01.002

Mukherjee, M. S., Chakraborty, S., \& De, M. P. (2020). Perception of Nursing Students on Effectiveness of Training-A Case Study on Red Cross Hospital, Silchar. International Journal of Advanced Science and Technology, $29(2), 3242-3253$.

Nawaz, M. A., Hussain, M. S., Kamran, H. W., Ehsanullah, S., Maheen, R., \& Shair, F. (2020). Trilemma association of energy consumption, carbon emission, and economic growth of BRICS and OECD regions: quantile regression estimation. Environmental Science and Pollution Research, 1-15.

Nguyen, H. H. (2020). Individual Customers' Access to Credits at Commercial Banks in Viet Nam: The Case of Tra Vinh Province. The Journal of Asian Finance, Economics, and Business, 7(9), 371-376. doi: https://doi.org/10.13106/jafeb.2020.vol7.no9.371 
Nguyen, N., Nguyen, T., Tran, T., \& Mai, A. (2020). Shrinkage Model Selection for Portfolio Optimization on Vietnam Stock Market. The Journal of Asian Finance, Economics, and Business, 7(9), 135-145. doi: https://doi.org/10.13106/jafeb.2020.vol7.no9.135

Nguyen, T.V.N, Giang, N.L (2021). The choice of capital structure: A study on energy industry in a developing country. Accounting, 7(2), 289-284. DOI: 10.5267/j.ac.2020.12.002

Nguyen, V. (2020). Human capital, capital structure choice and firm profitability in developing countries: An empirical study in Vietnam. Accounting, 6(2), 127-136.

Nguyen, D.T. (2020). The effect of financial structure on business performance of industrial enterprises listed in Vietnam. Accounting, 6(7), 1297-1304.

Nong, D., Nguyen, D. B., Nguyen, T. H., Wang, C., \& Siriwardana, M. (2020). A stronger energy strategy for a new era of economic development in Vietnam: A quantitative assessment. Energy policy, 144, 1-11. doi: https://doi.org/10.1016/j.enpol.2020.111645

Nong, D., Siriwardana, M., Perera, S., \& Nguyen, D. B. (2019). Growth of low emission-intensive energy production and energy impacts in Vietnam under the new regulation. Journal of cleaner production, 225, 90-103. doi: https://doi.org/10.1016/j.jclepro.2019.03.299

Nwoko, N. M., Ihemeje, J., \& Anumadu, E. (2016). The impact of monetary policy on the economic growth of Nigeria. African Research Review, 10(3), 192-206. doi: 10.4314/afrrev.v10i3.13

Paramati, S. R., Sinha, A., \& Dogan, E. (2017). The significance of renewable energy use for economic output and environmental protection: evidence from the Next 11 developing economies. Environmental Science and Pollution Research, 24(15), 13546-13560. doi: https://doi.org/10.1007/s11356-017-8985-6

Pirlogea, C., \& Cicea, C. (2012). Econometric perspective of the energy consumption and economic growth relation in European Union. Renewable and Sustainable Energy Reviews, 16(8), 5718-5726. doi: https://doi.org/10.1016/j.rser.2012.06.010

Sadiq, M., Pantamee, A. A., Mohamad, S., Aldeehani, T. M., \& Ady, S. U. (2020). Corporate governance and earnings management: evidence from listed non-financial firms. Polish Journal of Management Studies, $22(2), 456$.

Sadiq, M., Singh, J., Raza, M., \& Mohamad, S. (2020). The Impact of Environmental, Social and Governance Index on Firm Value: Evidence from Malaysia. International Journal of Energy Economics and Policy, 10(5), 555-562.

Salim, R. A., Hassan, K., \& Shafiei, S. (2014). Renewable and non-renewable energy consumption and economic activities: Further evidence from OECD countries. Energy Economics, 44, 350-360. doi: https://doi.org/10.1016/j.eneco.2014.05.001

Sasana, H., \& Ghozali, I. (2017). The impact of fossil and renewable energy consumption on the economic growth in Brazil, Russia, India, China and South Africa. International Journal of Energy Economics and Policy, 7(3), $194-200$.

Sean, M. (2019). The Impact of Monetary Policy on Economic Growth in Cambodia: Bayesian Approach. Journal of Management, Economics, and Industrial Organization, 3(2), 16-34. doi: http://doi.org/10.31039/jomeino.2019.3.2.2

Shobande, O. A., \& Shodipe, O. T. (2019). New Keynesian Liquidity Trap and Conventional Fiscal Stance: An Estimated DSGE Model. Economics and Business, 33(1), 152-169. doi: https://doi.org/10.2478/eb-2019-0011

Son, T. H., Liem, N. T., \& Khuong, N. V. (2020). Mobile Money, Financial Inclusion and Digital Payment: The Case of Vietnam. International Journal of Financial Research, 11(1), 417-424. doi: doi:10.5430/ijfr.v11n1p417

Soytas, U., \& Sari, R. (2009). Energy consumption, economic growth, and carbon emissions: challenges faced by an EU candidate member. Ecological economics, 68(6), 1667-1675. doi: https://doi.org/10.1016/j.ecolecon.2007.06.014

Sulaiman, L., \& Migiro, S. (2014). The nexus between monetary policy and economic growth in Nigeria: a causality test. Public and Municipal Finance, 3(2), 35-40.

Twinoburyo, E. N., \& Odhiambo, N. M. (2018). Can Monetary Policy drive economic growth? Empirical evidence from Tanzania. Contemporary Economics, 12(2), 207-222. doi: https://ideas.repec.org/p/uza/wpaper/21122.html

Othman, Z., Nordin, M. F. F., \& Sadiq, M. (2020). GST fraud prevention to ensure business sustainability: A Malaysian case study. Journal of Asian Business and Economic Studies, 27(3), 245-265.

Van Nguyen, H., Nguyen, C. D., Van Tran, T., Hau, H. D., Nguyen, N. T., \& Gummert, M. (2016). Energy efficiency, greenhouse gas emissions, and cost of rice straw collection in the Mekong River Delta of Vietnam. Field crops research, 198, 16-22. doi: https://doi.org/10.1016/j.fcr.2016.08.024

Wei, X., Che, H., Sheng, N., Hsiao, C., Tong, Q., \& Yan, G. (2020). Research on the Development Status of China's Renewable Energy Industry-The Impact of Capital Structure on Company Performance. Front. Energy Res, 8, 71-79. doi: doi: 10.3389/fenrg.2020.00071

Zhao, Z.-Y., Zuo, J., Fan, L.-L., \& Zillante, G. (2011). Impacts of renewable energy regulations on the structure of power generation in China-a critical analysis. Renewable Energy, 36(1), 24-30. doi: https://doi.org/10.1016/j.renene.2010.05.015 

under the terms and conditions of the Creative Commons Attribution (CC-BY) license (http://creativecommons.org/licenses/by/4.0/). 